\title{
Inhibition of Dipeptidyl Peptidase 4 (DPP IV) Activity by Some Indonesia Edible Plants
}

\author{
Muhammad Saiful Amin ${ }^{1,2}$, Fadlina Chany Saputri ${ }^{1}$, Abdul Mun'im ${ }^{1, *}$
}

\section{Muhammad Saiful Amin ${ }^{1,2}$, Fadlina Chany Saputri ${ }^{1}$, Abdul Mun'im 1,* \\ 'Graduate Programme of Herbal Medicine, Faculty of Pharmacy, \\ Universitas Indonesia, Depok, 16424, West Java, INDONESIA. \\ ${ }^{2}$ Graduate Student at Programme of Herbal Medicine, Faculty of Pharmacy, Universitas Indonesia, Depok, 16424, West Java, INDONESIA.}

\section{Correspondence}

\section{Dr. Abdul Mun'im}

Graduate Programme of Herbal Medicine, Faculty of Pharmacy, Universitas Indonesia, Depok, 16424, West Java, INDONESIA.

Phone no : +62 8111184550

E-mail: munim@farmasi.ui.ac.id

\section{History}

- Submission Date: 09-03-2018;

- Review completed: 27-04-2018;

- Accepted Date: 28-11-2018.

\section{DOI : 10.5530/pj.2019.11.36}

Article Available online http://www.phcogj.com/v11/i2

\section{Copyright}

(C) 2019 Phcog.Net. This is an openaccess article distributed under the terms of the Creative Commons Attribution 4.0 International license.

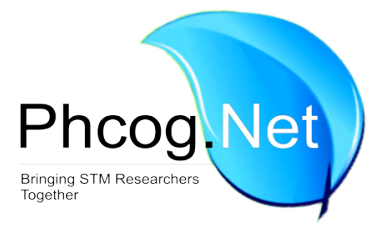

\begin{abstract}
Background: Some edible plants are promising to control blood sugar level. These plants contained phenolic substances that suggested to be able to inhibit dipeptidyl peptidase 4 (DPP IV). Objective: The objective of this study was to investigate the inhibitory effect of several selected Indonesia plants on inhibiting of DPP IV activity and to determine the total phenolic content of the most active extract. Methods: Twelve Indonesia edible plants were macerated using $80 \%$ ethanol at room temperature. DPP IV activity was evaluated by using glycyl-prolyl-7-amino-4-methyl coumarin (Gly-Pro-AMC) substrate and the inhibitory effect of extracts were determined based on the level of free AMC group by measuring its fluorescence on excitation wavelength 350-360 $\mathrm{nm}$ and an emission wavelength 450-465 nm using a microplate reader. Total phenolic contents of the active extracts were determined with Folin-Ciocalteu 1:4 on $765 \mathrm{~nm}$ using microplate reader. Total anthocyanins from extract were determined using the $\mathrm{pH}$ differential method. Results: Among the tested samples, the extract of Ipomoea batatas roots at a concentration of $10 \mu \mathrm{g} / \mathrm{mL}$ showed the highest inhibition, followed by Cajanus cajan leaves and Gnetum gnemon rind, with percentage inhibition of $28.8,24.9$ and 24.1 , respectively. I. batatas extract have an $I C_{50}$ value of $65.53 \mu \mathrm{g} / \mathrm{mL}$, while the $I_{50}$ value of the positive control Sitagliptin $9.37 \mu \mathrm{g} / \mathrm{mL}$. Total phenolic content from the extracts of I. batatas, C. cajan and G. gnemon rind extract were 279.3; 152.8; and $141.3 \mathrm{mg}$ GAE/gram, respectively. Total anthocyanin from I. batatas extract was $462.14 \mathrm{mg}$ cyanidin3-glucoside/L. Conclusion: The extract of $I$. batatas showed the highest inhibition on DPP IV among other plants investigated and showed high content of phenolic compound and anthocyanin that correlated with activity as inhibitor DPP IV.

Key words: Ipomoea batatas, Indonesian edible plant, Dipeptidyl Peptidase 4.
\end{abstract}

\section{INTRODUCTION}

Diabetes mellitus is a common endocrine disease and still a global health problem that requires serious treatment. The International Diabetes Federation (IDF) predicted patients with diabetes around the world will increase from 415 million, in 2015 , to 642 million, in 2040. ${ }^{1}$ Many medical therapeutic strategies are used for effective lowering glucose level in these patients such as (insulin sensitizer like glitazones and biguanides, $\alpha$ - glucosidase inhibitors, secretagogues as sulfonylurea and glinides, inhibitor enzyme dipeptidyl peptidase - IV and incretin mimetics). ${ }^{2}$

Incretins are hormones that are released from the gut into the bloodstream in response to ingestion of food. Gastric inhibitory polypeptide (GIP) and Glucagonlike peptide-1 (GLP-1) are the two primary incretin hormones secreted from the intestine to stimulate insulin secretion from pancreatic $\beta$ cells. ${ }^{3}$ Incretin effect accounts for at least $50 \%$ of the total insulin secreted after ingestion. In addition to its insulinotropic effects, it decreases food intake, inhibits glucagon secretion, inhibits gastric emptying and slows the rate of endogenous glucose production. ${ }^{4}$ It has also been shown to stimulate $\beta$-cell proliferation by up-regulation of the $\beta$-cell transcription factor pancreatic duodenal homeobox-1 protein (PDX-1) and to protect $\beta$ cells from apoptosis..$^{5-6}$

The main biological action of incretin (GIP and GLP-1) depends on their two N-terminal amino acid which is primarily removed by an enzyme dipeptidyl peptidase-4. Incretin (GIP and GLP-1) are metabolized into an inactive form rapidly by the enzyme DPP IV, about 1-2 min and only about $10-15 \%$ of circulating actively stimulate the pancreas. DPP IV is a member of the prolyl oligopeptidase family of serine proteases. DPP IV is an ectopeptidase implicated in the degradation of various peptides and hormones including glucagon family peptides, neuropeptides and chemokines. ${ }^{7}$

Inhibitor DPP IV group is now widely used for treating type 2 diabetes mellitus. These inhibitors promote glucose homeostasis by inhibiting DPP IV, the enzyme responsible for degrading two key glucoregulatory hormones (GIP and GLP-1). Clinical studies have evaluated the potential for DPP IV inhibition to reduce glucagon levels, delay gastric emptying 
and stimulate insulin release. DPP IV inhibitors appear to have excellent therapeutic potential in the management of type 2 diabetes. ${ }^{8}$

Some plants are known to contain phytochemicals that can help to treat various diseases such as diabetes. These plants that have been studied as an inhibitor of the enzyme DPP IV in vitro include semen of Trigonella foenum-graecum and leaves of Ficus religiosa. ${ }^{9}$ Phenolic compound such as flavonoids and stilbenoid, have been suggested as important compounds for diabetes reduction. ${ }^{10}$ Plants were selected based on empirical use as antidiabetic and their phytochemical content like stilbenoid, luteolin, apigenin and anthocyanin that reported have related to the inhibitory activity of enzyme DPP IV. ${ }^{11}$ The present study aims to screen the potential plants with inhibitory properties on DPP IV activity.

\section{MATERIAL AND METHODS}

\section{Chemicals}

DPP IV screening kit and sitagliptin were obtained from (Cayman, US), Folin-Ciocalteu and Gallic acid were purchased from (Sigma Aldrich), Sodium carbonate, potassium chloride and sodium acetate were purchased from (Merck).

\section{Plant materials}

A total of 12 Indonesian edible plants were collected from several places in Java, Indonesia. Allium sativum and Allium cepa tubers, aerial part of Apium graveolens and Petroselinum crispum, Cinnamomum zaelanicum stem bark, Ipomoea batatas and Rheum officinale rhizoma, Gnetum gnemon rind and seed, Foeniculum vulgare seed, Cajanus cajan leaves and Brassica oleracea flower. All plants were identified by Center for Plant Conservation-Bogor Botanical Garden, Indonesia.

\section{Preparation of samples}

The plant's materials were collected, cleaned dried, grounded to small pieces and stored in an airtight glass container. Each sample $(200 \mathrm{~g})$ was extracted with $2000 \mathrm{~mL}$ of $80 \%$ ethanol as the solvent for $2 \times 24 \mathrm{hrs}$ for each plant in room temperature. The ethanolic extracts then evaporated using a rotatory vacuum evaporator (Buchi, Switzerland).

\section{Inhibition of DPPIV assay}

The inhibition of DPP IV activity was performed using the enzyme protocol (Cayman DPP IV screening kit) with slight modification. Sitagliptin was used as the standard inhibitor. Briefly, $30 \mu \mathrm{L}$ of the buffer solution, $10 \mu \mathrm{L}$ of enzyme DPP IV, $10 \mu \mathrm{L}$ of sample solution (100 ppm) and $50 \mu \mathrm{L}$ Gly-Pro-AMC as the substrate, was added into the well. The mixture was shaken and incubated for $30 \mathrm{~min}$ at $37^{\circ} \mathrm{C}$ to have the complete reaction. In control wells, the inhibitor was replaced by aquabidest. The fluorescence of free AMC group was measured on excitation wavelength $350-360 \mathrm{~nm}$ and an emission wavelength $450-465 \mathrm{~nm}$ by using a microplate reader (GloMax ${ }^{\oplus}$ Discover System).

Percentage of inhibition was calculated using the formula:

$$
\% \text { Inhibition }=\frac{\text { Initial Activity }- \text { Inhibitor }}{\text { Initial Activity }} \times 100
$$

The $\mathrm{IC}_{50}$ value represents the concentration of inhibitor required to achieve $50 \%$ enzyme inhibition.

\section{Phytochemical screening}

Qualitative identification of phytochemical constituent in the extracts was performed by using standard analytical procedures with slight modification. ${ }^{12-13}$ Alkaloid test with Bouchardat, Dragendorff and Mayer reagents; Tannin test with ferrous (III) chloride, gelatin test and gelatinsalt test; Flavonoid test with Wilson-Taoubock and Shinoda reaction; Glycoside test with Molisch reaction; Saponin test with foaming test;
Terpenoid test with Liebermann-Burchard reagent; Anthraquinone test with Borntrager reaction.

\section{Determination of the total phenolic content}

The total phenolic content determination was based on the 96-well microplate Folin-Ciocalteu method given by Ahmad, 2017 with slight modifications. ${ }^{14}$ A total of $20 \mu \mathrm{L}$ of the extract solution or standard solution were mixed with $100 \mu \mathrm{L}$ of 1:4 diluted Folin-Ciocalteu reagent and homogenized for $1 \mathrm{~min}$ in a flat-bottom 96-well microplate. The mixture was left for $4 \mathrm{~min}$ and then $75 \mu \mathrm{L}$ of sodium carbonate solution $(100 \mathrm{~g} / \mathrm{L})$ were added and homogenized for $1 \mathrm{~min}$. After $2 \mathrm{hrs}$ at room temperature in the dark, the absorbance was measured at $765 \mathrm{~nm}$ using the microplate reader 96 well (VersaMax ${ }^{\text {TM }}$ ELISA Microplate Reader, USA). The absorbance of the same reaction with ethanol instead of the extract or standard was subtracted from the absorbance of the reaction with the sample. Gallic acid solutions (10-200 mg/L) was used as standards for calibration.

The yield of GAE in extracts was determined by comparison of absorbance with standards. The calibration curve of standards (gallic acid) was measured by the absorbance from the microplate reader instrument and was calculated using SoftMax 6.5.1 software. The equation formula was $\mathrm{Y}==6.6409 \mathrm{x}+121.82$ and $\mathrm{R} 2=0.9947$, where $\mathrm{Y}$ is the yield of GAE (total polyphenolic content) and $\mathrm{X}$ is the absorbance of gallic acid or samples.

\section{Determination of total anthocyanin from I. batatas root extracts}

The total anthocyanin from extracts were determined using the $\mathrm{pH}$ differential method (Lee et al. 2005). Prepared two solutions of extract, the first solution for $\mathrm{pH} 1$ and the second solution for $\mathrm{pH}$ 4.5. Take each $1 \mathrm{ml}$ of extract solution and diluted using ph solution into $5 \mathrm{ml}$. After $20 \mathrm{~min}$ at room temperature, the absorbance from each dilution are measured using Spectrophotometer UV-Vis at 520 and $700 \mathrm{~nm}$. To determine its absorbance value by using the following formula:

$$
\mathrm{A}=\left(\mathrm{A} \lambda_{520 \mathrm{~nm}}-\mathrm{A} \lambda_{700 \mathrm{~nm}}\right) \mathrm{pH} 1,0-\left(\mathrm{A} \lambda_{520 \mathrm{~nm}}-\mathrm{A} \lambda_{700 \mathrm{~nm}}\right) \mathrm{pH} 4,5
$$

Calculate anthocyanin pigment concentration, expressed as cyanidin3-glucoside equivalents, as follows:

$$
\text { Total anthocyanin pigment }(\mathrm{mg} / \mathrm{g})=\frac{\mathrm{A}^{\star} \mathrm{MW} \mathrm{DF}^{\star} \mathrm{DF} 10^{3}}{\varepsilon^{\star} 1}
$$

where $\mathrm{A}=(\mathrm{A} 520 \mathrm{~nm}-\mathrm{A} 700 \mathrm{~nm}) \mathrm{pH} 1.0-(\mathrm{A} 520 \mathrm{~nm}-\mathrm{A} 700 \mathrm{~nm}) \mathrm{pH} 4.5$; MW (molecular weight $)=449.2 \mathrm{~g} / \mathrm{mol}$ for cyanidin-3-glucoside (cyd-3-glu); $\mathrm{DF}=$ dilution factor; $\mathrm{l}=$ pathlength in $\mathrm{cm} ; \mathrm{V}=$ volume of extract $(\mathrm{ml})$; ( $\varepsilon=26900$ molar extinction coefficient; and $10^{3}=$ factor for conversion from $g$ to $\mathrm{mg} ; \mathrm{M}_{\mathrm{f}}=$ sample weight $(\mathrm{g})$.

\section{Chromatogram analysis from PSP extract}

An isocratic Reversed-phase high-performance liquid chromatography (HPLC) using Agilent 1100 (Palo Alto, USA) with UV-Vis diode array detection was used to determined chromatogram anthocyanins from PSP extract. PSP extract was injected into the HPLC with the following operational conditions: mobile phase was $10 \%$ glacial acetic acid in distilled water : acetonitrile (85: $15 \mathrm{v} / \mathrm{v})$, Prodigy C18 reversed-phase column $(5 \mathrm{~mm}), 4.6 \times 150 \mathrm{~mm}$ i.d. (Agilent, USA), volume injection was $20 \mu \mathrm{L}$, flow rate was $1 \mathrm{~mL} / \mathrm{min}$, detector UV-Vis at $530 \mathrm{~nm}$ and column temperature was $30^{\circ} \mathrm{C}$. Separation of anthocyanin was carried out for $20 \mathrm{~min}$. 


\section{RESULTS}

\section{Inhibition of DPP IV by some Indonesia edible plant}

The inhibitory effect on DPP IV activity was performed by in vitro method using Gly-Pro-AMC as a substrate. DPP IV converts Gly-Pro-AMC into Gly-Pro and AMC. The activity on DPP IV inhibition was evaluated based on the level of AMC by measuring its fluorescence using microplate reader (GloMax ${ }^{\oplus}$ Discover System). The activity was measured quantitatively in the presence or absence of the extract. Sitagliptin was used as the positive control that showed percentage inhibition with the value of $90.09 \%$ at $100 \mu \mathrm{M}$. The Inhibition of DPP IV by sitagliptin at various concentration is shown in Figure 1.

Only ten from twelve plants showed inhibition activity of DPP IV at $10 \mu \mathrm{g} / \mathrm{mL}$ final concentration. Ethanolic extract of I. batatas, C. cajan and G. gnemon gave the highest activity with percentage inhibition of 24.1 to 28.80 at $10 \mu \mathrm{g} / \mathrm{mL}$ final concentration. I. batatas extract showed the most potent activity with percentage inhibition of 28.80 . The extract was further investigated for effect at the various concentration to obtain the $\mathrm{IC}_{50}$ value. The percentage inhibition of the extracts and $\mathrm{IC}_{50}$ value of the extract is shown in Table $\mathbf{1}$ and Figure 2.

\section{Phytochemical screening}

I. batatas, C. cajan and G. gnemon extracts were further investigated to determine the phytochemical content that responsible for their activity. The common phytochemicals content from the plant such as flavonoid, alkaloid, terpenoid, steroid, tannin, glycoside and saponin have been identified (Table 2).

\section{Total phenolic content}

The total phenolic contents from the extracts of I. batatas, C. cajan and G. gnemon were determined with Folin-Ciocalteu method with equivalent to gallic acid. Orders of the total phenolic content from highest lowest were I. batatas $>$ C. cajan $>$ G. gnemon extracts (Table 3).

\section{Total anthocyanin content from I. batatas roots extract}

The content of anthocyanins from I. batatas extract was determined using $\mathrm{pH}$ differential method to be $462.14 \pm 14.27 \mathrm{mg} / \mathrm{L}$ (expressed as cyanidin-3-glucoside).

\section{HPLC analysis of purple sweet potato anthocyanins}

The chromatogram from the ethanolic extract of I. Batatas is shown in Figure 3.

\section{DISCUSSION}

\section{Inhibition of DPP IV by some Indonesia edible plant}

In the present study, the effect of extracts on enyzme DPP IV activity is shown in dose-dependent manner. Sitagliptin is the potent DPP IV inhibitor for management T2DM. DPP IV is associated with degradation 85-95\% of two key glucoregulatory hormones (GIP and GLP-1). Blockade of the DPP IV activity can prevent degradation of (GIP and GLP-1) that its contribute to increased insulin secretion, inhibit glucagon secretion, stimulate $\beta$-cell proliferation and protect $\beta$-cell from apoptosis.

The results demonstrated that $80 \%$ ethanol extract of I. batatas, C. cajan leaves and G. gnemon rind gave the highest activity with percentage inhibition of 24.1 to 28.80 at $10 \mu \mathrm{g} / \mathrm{mL}$ final concentration. I. batatas extract showed the most potent activity with percentage inhibition of 28.80. Most of the recent studies revealed that the inhibitory activity of DPP IV is due to the phenolic content in plant. Alkaloid, flavonoid and stilbenoid have been reported to have activity as a DPP IV inhibitor. ${ }^{15-17}$ The result demonstrated that extract $I$. batatas roots was the strongest inhibitor of DPP IV activity in vitro, followed by C. cajan leaves and
G. gnemon rind. Some extracts showed inhibition activity which indicates that the extracts contained potential compound as DPP IV inhibitor. I. batatas roots was the strongest inhibitor of DPP IV activity in vitro with $\mathrm{IC}_{50}$ value $65.53 \mu \mathrm{g} / \mathrm{mL}$. I. batatas roots have been used as foodstuffs in daily life in Indonesia. This plant also was used as traditional medicine as a substitute source of carbohydrates for diabetes management. But, the scientific data is limited. From this study, we can conclude that I. batatas roots showed a mechanism action as DPP IV inhibitor.

\section{Phytochemical screening}

I. batatas, C. cajan and G. gnemon extract were further investigated to determine the source of activity. The common phytochemistry content from plants such as flavonoid, alkaloid, terpenoid, steroid, tannin, glycoside and saponin have identified (Table 2). Most of the recent studies revealed that the inhibitory activity of DPP IV is due to the phenolic content in the plant. Alkaloid, flavonoid and stilbenoid have been reported to have activity as a DPP IV inhibitor. ${ }^{15-17}$

DPP IV has three active sites (S1, S2, and S3). The specificity S1 is composed of the side chains of catalytic triad (Ser630, Asn710, and His740), which are involved in strong hydrophobic interactions. The active site S2 of DPP IV is cavity near Glu205, Glu206, and Tyr662 residues. And the active site S3 consists of Ser209, Arg358 and Phe357. The inside position of the active site S3 in DPP-IV allows smaller groups access to the site; on the other hand, the outside position of the S3 favors larger groups. ${ }^{18} \mathrm{DPP}-4$ inhibitors interact with the active site $\mathrm{S} 2$ at Glu205 and Glu206 by forming salt bridges. This interaction plays an important role in inhibiting the enzyme. ${ }^{19}$

Based on previous research, these three plants have been reported to have activity as antidiabetes. Administration of G. gnemon extract, Anthocyanin from I. batatas and ethanolic extract C. cajan leaves can decrease blood glucose level in animal test. ${ }^{20-22}$ Although the antidiabetic activity of G. gnemon, I. batatas and C. cajan has been reported, its ability to inhibit DPP IV activity had not been studied so far. This is the first report indicated that ethanolic extracts of G. Gnemon rind, I. Batatas roots and C. cajan leaves showed significant DPP IV inhibitory activity. The results of this study may explain the mechanism of the extracts in lowering blood sugar levels.

In this study, I. batatas extract showed the highest DPP IV inhibitor activity in vitro with an $\mathrm{IC}_{50}$ value of $65.53 \mu \mathrm{g} / \mathrm{mL}$ comparable with sitagliptin $9.37 \mu \mathrm{g} / \mathrm{mL}$. Ethanolic extract I. batatas extract contains high amount of total anthocyanins. ${ }^{23}$ SwissDock computational docking study demonstrated that anthocyanins were able to interact with DPP IV through ligand interaction and therefore potentially inactivate the activity of the enzyme. ${ }^{24}$ We suggested the anthocyanins contained in I. batatas extract is most responsible for its activity as a DPP 4 inhibitor.

\section{Total phenolic content}

Total phenolic content from $80 \%$ ethanolic extracts of Ipomoea batatas roots, Cajanus cajan leaves and Gnetum gnemon rind are shown in Table 3.

The relationship between DPP IV inhibitory activity of I. batatas, C. cajan and G. gnemon extracts with their phenolic content was established using analysis bivariate pearson comparison. The result significantly indicated a high relationship between total phenolic content with DPP IV inhibitory activity $(p<0.05)$ with correlation value was 0.916 . A number of natural products have previously been found to have DPP-IV inhibitory activities and most of them contain polyphenols, flavonoids and alkaloids as the active components. ${ }^{25}$

\section{Total anthocyanin content from I. batatas roots extract}

The content of anthocyanins from $I$. batatas extracts were determined using $\mathrm{pH}$ differential method to be $462.14 \pm 14.27 \mathrm{mg} / \mathrm{L}$. Previous research reported that the highest anthocyanin content from $I$. batatas was $687.58 \mathrm{mg} / \mathrm{L}$, which was reached at the best condition extraction. ${ }^{26}$ 
Table 1. Inhibition (\%) of the ethanolic extracts of some Indonesian edible plants on DPP IV Activity

\begin{tabular}{|c|c|c|c|c|}
\hline No. & Plant Species & Family & $\begin{array}{l}\text { Part of } \\
\text { The Plant }\end{array}$ & $\begin{array}{c}\text { Inhibition } \\
\text { of DPP IV } \\
(\%)\end{array}$ \\
\hline 1 & Allium сера & Liliaceae & Tubers & nil \\
\hline 2 & Allium sativum & Liliaceae & Tubers & $13 \pm 4.87$ \\
\hline 3 & Apium graveolens & Apiaceae & Aerial part & $6.3 \pm 1.98$ \\
\hline 4 & $\begin{array}{l}\text { Petroselinum } \\
\text { crispum }\end{array}$ & Apiaceae & Aerial part & $18 \pm 5.93$ \\
\hline 5 & $\begin{array}{l}\text { Cinamomum } \\
\text { zeylanicum }\end{array}$ & Lauraceae & Stem barks & $8.5 \pm 4.24$ \\
\hline 6 & $\begin{array}{l}\text { Ipomoea batatas } \\
\text { (L). (purple) }\end{array}$ & Convolvulaceae & Roots & $28.8 \pm 7.7$ \\
\hline 7 & $\begin{array}{l}\text { Gnetum gnemon } \\
\text { (L) }\end{array}$ & Gnetaceae & Seeds & $16.0 \pm 2.76$ \\
\hline 8 & $\begin{array}{l}\text { Gnetum gnemon } \\
\text { (L) }\end{array}$ & Gnetaceae & Rinds & $24.1 \pm 7.7$ \\
\hline 9 & $\begin{array}{l}\text { Foeniculum } \\
\text { vulgare Mill. }\end{array}$ & Apiaceae & Seeds & nil \\
\hline 10 & $\begin{array}{l}\text { Cajanus cajan } \\
\text { (L). Millsp. }\end{array}$ & Fabaceae & Leaves & $24.9 \pm 3.2$ \\
\hline 11 & $\begin{array}{c}\text { Rheum officinale } \\
\text { Baill. }\end{array}$ & Polygonaceae & Roots & $10.4 \pm 4.45$ \\
\hline 12 & $\begin{array}{l}\text { Brassica olera- } \\
\quad \text { cea } \mathrm{L} .\end{array}$ & Brassicaceae & Flower & $9.32 \pm 2.88$ \\
\hline
\end{tabular}

Final concentration of the extract solution in the DPP IV inhibition assay was $10 \mu \mathrm{g} / \mathrm{ml}$.

Data are mean \pm SEM for triplicate measurements.

$\mathrm{Nil}=$ no inhibition detected at the assayed concentration

\section{Table 2 : Phytochemical screening of the most active extracts}

\begin{tabular}{cccc}
\hline $\begin{array}{c}\text { Phytochemical } \\
\text { Constituents }\end{array}$ & $\begin{array}{c}\text { Ipomoea batatas } \\
\text { roots }\end{array}$ & $\begin{array}{c}\text { Cajanus cajan } \\
\text { leaves }\end{array}$ & $\begin{array}{c}\text { Gnetum } \\
\text { gnemon rind }\end{array}$ \\
\hline Alkaloids & + & + & + \\
Flavonoid & ++ & ++ & ++ \\
Saponin & ++ & + & + \\
Glycoside & + & + & + \\
Antraquinones & - & - & - \\
Terpenoids & + & + & + \\
Steroid & + & + & + \\
Tannin & + & + & - \\
\hline
\end{tabular}

Key: $-=$ absent,$+=$ present in small amount, $++=$ present in moderate quantity

\section{Table 3 : Total phenolic content}

\begin{tabular}{cc}
\hline Sample & Total phenolic content (mgGAE/gram) \\
I. batatas extract & $279.3 \pm 40.3$ \\
C. cajan extract & $152.8 \pm 15.1$ \\
G. gnemon extract & $141.3 \pm 37.02$ \\
\hline Data are mean \pm SEM for triplicate measurements.
\end{tabular}

Data are mean \pm SEM for triplicate measurements.

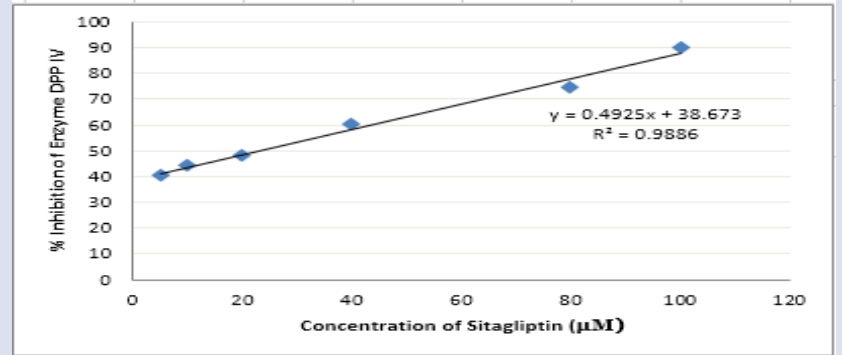

Figure 1: Inhibition of DPP IV by Sitagliptin at Various Concentration.

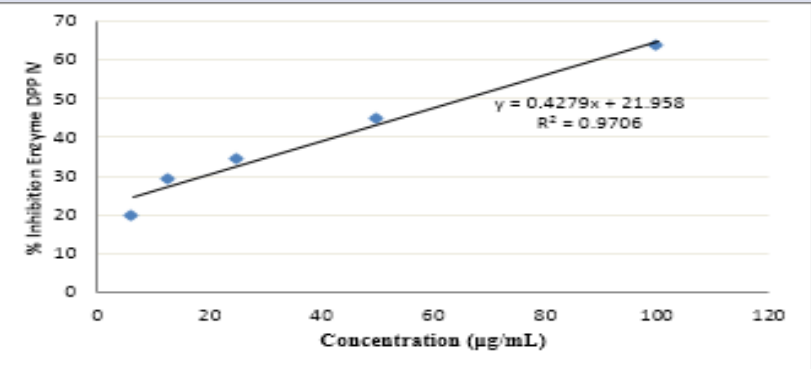

Figure 2: The IC $\mathrm{C}_{50}$ Of DPP IV Inhibition By Ipomoea Batatas Roots Extract

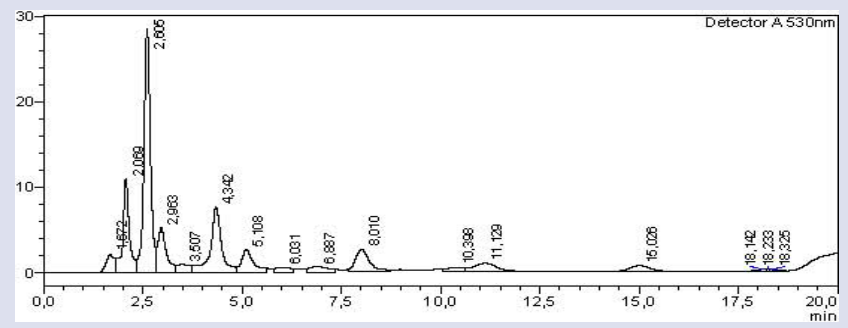

Figure 3: The chromatogram from the ethanolic extract of I. Batatas.

The appropriate anthocyanin content of the materials ranged from 20 to $3000 \mathrm{mg} / \mathrm{L}$ (expressed as cyanidin-3-glucoside). Compared with other plants, such as blueberry juice ${ }^{27}(424.1$ to $518.2 \mathrm{mg} / \mathrm{L}$ ) and strawberry juice $^{28}(55.7 \mathrm{mg} / \mathrm{L})$, the content of anthocyanin was relatively high in I. batatas.

\section{HPLC analysis of purple sweet potato anthocyanins}

HPLC analysis shows that 10 main peaks appeared in the chromatograms of purple sweet potato anthocyanins, which were detected at 530 $\mathrm{nm}$. From the chromatographic and UV - visible spectral features, peaks 1 to 10 were accounting for $3,12.9,15.6,33.4 \%, 15.42,5.66,2.3,6.7,3.7$ and $2.8 \%$ respectively, of the total amount of all the anthocyanins. As a 
group of phenolic compounds, hundreds of anthocyanins have been isolated from nature. The most common anthocyanins found in fruits and vegetables are cyanidin, malvidin peonidine, and delphinidin. The main anthocyanins in PSP are cyanidin and peonidin which are glycosylated with sugar. ${ }^{29}$ Tian et al, (2005) showed that glycosylated anthocyanins are generally mono or acylated with hydroxybenzoic, ferulic and caffeic acids. ${ }^{30}$ This structural complication leads to a major challenge for anthocyanin identification from PSP.

\section{CONCLUSION}

The results of in vitro test indicate that out of the twelve plant extracts, ethanolic extracts of Ipomoea batatas extract showed the highest DPP IV inhibitory activity and showed high content of phenolic compound and anthocyanin that correlated with activity as inhibitor DPP IV. The plant may essentially contain phytochemical compounds that can inhibit enzyme activity and further characterization methodologies and structural elucidation have to be carried out in order to identify the bioactive constituents. The expected bioactive components could be anthocyanins or other polyphenols because the literature shows the relationship between polyphenols and inhibition of DPP IV. In conclusion, more research is required for developing a potential DPP IV inhibitor of plant origin.

\section{ACKNOWLEDGEMENT}

This study was supported by Directorate General of Higher Education, Ministry of National Education, Republic Indonesia via hibah PITTA 2017.

\section{CONFLICT OF INTEREST}

The authors declare no conflict of interest.

\section{ABBREVIATIONS}

DPP IV: dipeptidyl peptidase iv; Gly-Pro-AMC: Glycyl-prolyl7-Amino-4-Methyl Coumarin; GIP: Gastric inhibitory polypeptide; GLP-1: Glucagonlike Peptide-1, PDX-1: Pancreatic Duodenal Homeobox-1 protein; GAE: Galic Acid Equivalent; PSP: Purple Sweet Potatoes.

\section{REFERENCES}

1. IDF (International Diabetes Federation), Diabetes Atlas. 2015. Available from www.eatlas.idf.org.

2. Alberti KG, Zimmet PZ, Definition, diagnosis and classification of diabetes mellitus and its complications. Diabet Med. 1998;15(7):539-53.

3. Kim W, Egan JM. The Role of Incretins in Glucose Homeostasis and Diabetes Treatment. NIH Public Access. 2009;60(4):470-512

4. Prigeon RL, Quddusi S, Paty B, D'Alessio DA. Suppression of glucose production by GLP-1 independent of islet hormones: a novel extrapancreatic effect. Am J Physiol Endocrinol Metab. 2003;285(4):E701-7.

5. Farilla L, Bulotta A, Hirshberg B, Li Calzi S, Khoury N, Noushmehr H, et al. Glucagon-like peptide 1 inhibits cell apoptosis and improves glucose responsiveness of freshly isolated human islets. Endocrinology. 2003;144(12): 5149-58.

6. Farilla L, Hui H, Bertolotto C, Kang E, Bulotta A, Di Mario U, et al. Glucagon-like peptide-1 promotes islet cell growth and inhibits apoptosis in Zucker diabetic rats. Endocrinology. 2002;143(11):4397-408.

7. Mentlein R, Dahms P, Grandt D, Kruger R. Proteolytic processing of neuropeptide $Y$ and peptide YY by dipeptidyl peptidase IV. Regul Pept. 1993;49(2):133-44.

8. Langley AK, Suffoletta TJ, Jennings HR. Dipeptidyl peptidase IV inhibitors and incretin system in type 2 Diabetes Mellitus. Pharmacoterapy. 2007;27(8):1163.

9. Riyanti S, Suganda AG, Sukandar EY. Dipeptidyl Peptidase IV Inhibitory Activity of Some Indonesian Medicinal Plants. Asian Journal of Pharmaceutical and Clinical Research. 2016;9(2):375-7.

10. Semighini EP, Resende JA, De Andrade $P$, et al. Using computer-aided drug design and medicinal chemistry strategies in the fight against diabetes. Journal of Biomolecular Structure and Dynamics. 2011;28(5):787-96.

11. Fan J, Johnson MH, Lila MA, Yousef G, Mejia EGD. Berry and Citrus Phenolic Compounds Inhibit Dipeptidyl Peptidase IV: Implications in Diabetes Management.
Evidence-Based Complementary and Alternative Medicine. 2013;2013

12. Harborne JB. Phytochemical methods. London. Chapman and Hall. 1998.

13. Kokate CK. A textbook of Practical Pharmacognosy. Vallabh Prakashan $5^{\text {th }}$ edn. 2005;107-11.

14. Ahmad I, Yanuar A, Mulia K, Mun'im A. Optimization of ionic liquid-based microwave-assisted extraction of polyphenolic content from Peperomia pellucida (L) kunth using response surface methodology. Asian Pacific Journal of Tropical Biomedicine. 2017;7(7):660-5.

15. Kumar S, Krishnan S, Kumar A, Kishore K, Murari K, Kumar B, et al. Phytomedicine Antihyperglycemic activity with DPP-IV inhibition of alkaloids from seed extract of Castanospermum australe: Investigation by experimental validation and molecular docking. European Journal of Integrative Medicine. 2012;20(1):24-31.

16. Bower AM, Hernandez LMR, Berhow MA, Mejia EGD. Bioactive Compounds from Culinary Herbs Inhibit a Molecular Target for Type 2 Diabetes Management. Journal of Agricultural and Food Chemistry. 2014;62(26):6147-58.

17. Ahmed G, Meligy E. Effect of Resveratrol on Dipeptidyl Peptidase-4 (DPP-4) and Phospho Enol Pyruvate Carboxy Kinase (PEPCK) in Streptozotocin Induced Diabetic Rats. Bull Egypt Soc Physiol Sci. 2011;31(1):1-14.

18. Pissurlenkar RRS, Shaikh MS, Coutinho EC. 3DOSAR studies of Dipeptidyl peptidase IV inhibitors using a docking based alignment. Journal of Molecular Modeling. 2007;13(10):1047-71.

19. Kimata H, Fukuda-Tsuru S, Yoshida K, Iwasaki S, Kiuchi S, Akahoshi F, et al. Teneligliptin, a novel selective dipeptidyl peptidase-4 inhibitor, improves postprandial hyperglycemia in a model of type 2 diabetes, zucker diabetic fatty rats. Med Consult New Remedies. 2012;49:9.

20. Said RB, Sunilson JAJ, Latiff AA, Anandarajagopal K. Antidiabetic Activity of Gnetum gnemon Fruits Against Type 2 Diabetes. American Journal of Pharmatech Research. 2017;7(1).

21. Jawi M, Putu W, Suprapta D, Mahendra A. Hypoglycemic and Antioxidant Activities of Balinese Purple Sweet Potato (/pomoea batatas $L$ ) in Induced- Diabetic Rats. CIBTech Journal of Pharmaceutical Science. 2012;1:1-6.

22. Alberto J, Manzo M, Jonathan R, Vitor S. Antihyperglycemic effects of Cajanus cajan $\mathrm{L}$. (pigeon pea) ethanolic extract on the blood glucose levels of ICR mice (Mus musculus L). Nat Journal of Physiology, Pharmacy and Pharmacology. $2017 ; 7(8): 860-4$

23. Sugata M, Lin C, Shih Y. Anti-Inflammatory and Anticancer Activities of Taiwanese Purple-Fleshed Sweet Potatoes (/pomoea batatas L.Lam) Extracts. BioMed Research International. 2015;2015.

24. Johnson MH, De Mejia EG, Fan J, Lila MA, Yousef GG. Anthocyanins and proanthocyanidins from blueberry-blackberry fermented beverages inhibit markers of inflammation in macrophages and carbohydrate-utilizing enzymes in vitro. Mol Nutr Food Res. 2013;57(7):1182-97.

25. Rachpirom M, Ovatlarnporn C, Thengyai S, Sontimuang C, Puttarak P. Dipeptidyl Peptidase-IV (DPP-IV) Inhibitory Activity, Antioxidant Property and Phytochemical Composition Studies of Herbal Constituents of Thai Folk Anti-Diabetes Remedy. Walailak Journal. 2013;13(10):803-14.

26. Agung LW, Yunianta, Dewanti TW. Anthocyanin extraction from purple sweet potato cultivar Antin-3 (Ipomoea batatas L.) using maceration, microwave assisted extraction, ultrasonic assisted extraction and their aplication as anti-hiperglicemic agents in alloxan induced wistar rat. International Journal of PharmTech Research. 2016;9(3):181-92.

27. Rossi, et al. Effect of fruit blanching on phenolics and radical scavenging activity of highbush blueberry juice. Food Research International. 2003;36(9-10):999-1005.

28. Torreggiani, et al. Modification of glass transition temperature through carbohydrates additions: effect upon colour and anthocyanin pigment stability in frozen strawberry juices. Food Research International. 1999;32(6):441-6.

29. Fan G, Han Y, Gu Z, Gu F. Composition and colour stability of anthocyanins extracted from fermented purple sweet potato culture. LWT - Food Science and Technology. 2008;41(8):1412-6. http://dx.doi.org/10.1016/j.Iwt.2007.09.003.

30. Tian Q, Konczak I, Schwartz SJ. Probing anthocyanin profiles in purple sweet potato cell line (Ipomoea batatas L. Cv. Ayamurasaki) by high-performance liquid chromatography and electrospray ionization tandem mass spectrometry. Journal of Agricultural and Food Chemistry. 2005;53(16):6503-9. http://dx.doi. org/10.1021/jf050671m. PMid:16076141 
GRAPHICAL ABSTRACT

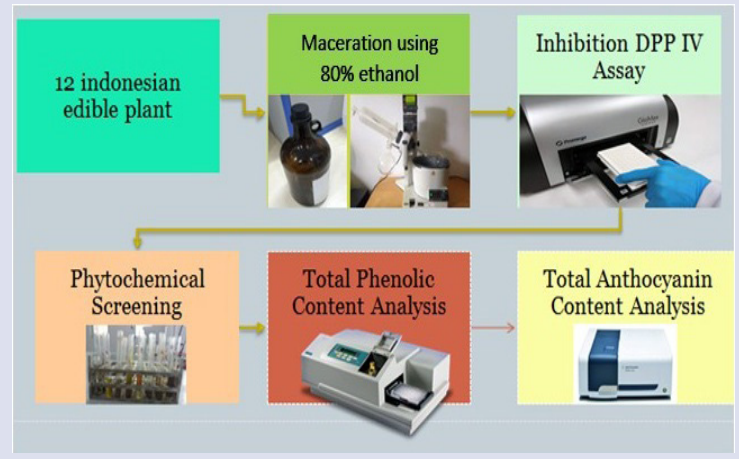

\section{SUMMARY}

- Ten from twelve Indonesian edible plants showed inhibition activity of DPP IV

- Ethanolic extract of I. batatas, C. cajan and G. gnemon gave the highest activity with percentage inhibition of 24.1 to 28.80 at $10 \mu \mathrm{g} / \mathrm{mL}$.

- I. batatas extract showed the highest DPP IV inhibitor activity in vitro with an $\mathrm{IC}_{50}$ value of $65.53 \mu \mathrm{g} / \mathrm{mL}$

- The content of anthocyanins from $/$. batatas extracts was $462.14 \pm 14.27 \mathrm{mg} / \mathrm{L}$

\section{ABOUT AUTHORS}

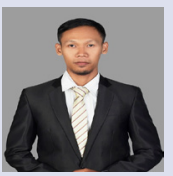

Muhammad Saiful Amin: is a master student at Department of Pharmaceutical Sciences, Faculty of Pharmacy, Universitas Indonesia (UI) Depok, West Java, Indonesia. The master research focused on the study of lonic liquid and development of extraction method.

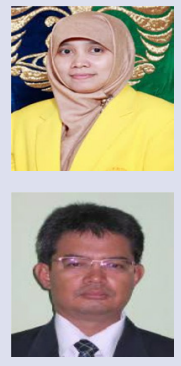

Fadlina Chany Saputri: is an Associate Professor at Department Pharmacology-Toxicology, Faculty of Pharmacy, Universitas Indonesia (UI) Depok, West Java, Indonesia. Her research focused on herbal plants and its activity on degenerative disease (such as diabetes mellitus, antihypertension, and other cardiovascular disease)

Abdul Mun'im: Ph.D., is an Associate Professor at Department Pharmaceutical Sciences, Faculty of Pharmacy, Universitas Indonesia (UI) Depok, West Java, Indonesia. He has experience in the area of Pharmacognosy and Phytochemistry, working in drugs discovery of herbal plants, extraction technology, metabolite profiling, structure elucidation and degenerative disease (such as diabetes mellitus, antihypertension, and cholesterol).

Cite this article: Amin MS, Saputri FC, Mun'im A. Inhibition of Dipeptidyl Peptidase 4 (DPP IV) Activity by Some Indonesia Edible Plants. Pharmacog J. 2019;11(2):231-6. 